\title{
Physiological and pathophysiological role of somatostatin receptors in the human thymus
}

\author{
Diego Ferone ${ }^{1,3}$, P Martin van Hagen ${ }^{2}$, Rosario Pivonello ${ }^{1,3}$, Annamaria Colao ${ }^{3}$, Steven W J Lamberts ${ }^{1}$ and \\ Leo J Hofland ${ }^{1}$ \\ ${ }^{1}$ Department of Internal Medicine and ${ }^{2}$ Department of Immunology, Erasmus University, Rotterdam, The Netherlands, and ${ }^{3}$ Department of Molecular \\ and Clinical Endocrinology and Oncology, 'Federico II' University, Naples, Italy
}

(Correspondence should be addressed to D Ferone, Department of Internal Medicine, University Hospital Dijkzigt, Dr Molewaterplein 40, 3015 GD Rotterdam, The Netherlands)

\section{Introduction}

The functional interactions between the immune, endocrine and nervous systems occur at different levels, which underline their relevance in controlling physiological processes. Any disturbances herein may be potentially involved in certain pathological conditions $(1,2)$. Studies in animal models have demonstrated that abnormalities in immune-neuroendocrine communications may start or contribute to the development of chronic autoimmune diseases. By analogy, similar questions have been raised for humans. Neuroendocrine and immune systems share a number of ligands and related receptors (3). The majority of these signalling molecules are highly conserved and, via these products, the systems in many species are able to establish sophisticated physiological intra- and intersystem communication circuits (4). The bidirectional neuroendocrine-immune interactions may constitute an important homeostatic mechanism (5).

In their physiological environment, immune cells are exposed to agents such as hormones and neuropeptides. These cells can produce hormones and neuropeptides themselves and may express specific receptors for neuroendocrine regulatory peptides as well (6-8). In addition, lymphoid tissues are directly and extensively innervated, the nerve fibres being in direct contact with lymphocytes or their precursors as well as macrophages, performing their neuro-effector functions.

In Table 1 the principal neuropeptides involved in controlling the immune system are indicated together with their effects on immune function. The distribution of neuropeptide receptors in the immune system has some common characteristics. Their expression pattern on different types of immune cells is heterogeneous, suggesting that the signal mediated by these agents can preferentially target different types of immune responses. Another important aspect is that the number or the activity of neuropeptide receptors on immunocytes may change during the specific and aspecific activation of these cells, suggesting that signals mediated by one of this effectors could be predominantly perceived by antigen-activated cells (1). This evidence may partially explain the rather common occurrence of conflicting observations that neuroendocrine-mediated activities exert on immune cells.

Many recent studies have pointed to the presence and functional roles of somatostatin (SS) and its receptors on the cells of the immune system $(9,10)$. SS is a peptide hormone widely distributed throughout the human body, involved in regulating neurotransmission in the brain, as well as secretion processes in the anterior pituitary gland, the pancreas and the gastrointestinal tract (11-13). An antiproliferative action of SS has been observed in many cell types in vitro as well (12). Five different SS receptor (SST) genes originate multiple SST subtypes $\left(\mathrm{sst}_{1-5}\right)$ and, although the genes have a high degree of sequence homology, they are localized on different chromosomes, which allows a tissue-specific regulation of their expression and suggests diverse functions of the receptor subtypes in different organs (14-17). The five SST subtypes bind native SS with high affinity but can be further divided into two subclasses on their ability to bind structural octapeptide SS analogues. Three octapeptide SS analogues, octreotide, lanreotide and vapreotide, have already been introduced into clinical practice (Fig. 1). sst $_{1}$ and sst $_{4}$ receptors do not bind these analogues, whereas $\mathrm{sst}_{2 \mathrm{~A}}$, sst $_{3}$ and sst $_{5}$ receptors display a high, low and moderate affinity, respectively, towards octapeptide SS analogues.

Among lymphatic organs, the thymus from different species, including the human, has been shown to contain the highest amount of SS $(7,8,18)$. Although experimental models in animals have suggested the significant participation of different neuropeptides in the activities of the thymus, the exact role of SS in this context is still obscure.

\section{SS and SST in the thymus}

\section{Structure and function of the human thymus}

The thymus is a central lymphoid organ in mammals and it plays a pivotal role in the control of the immune system. The presence of the thymus and its functionality are required for full establishment of immunocompetence. The thymus involutes with constant velocity 
Table 1 Effects of neuropeptides on immune functions.

\begin{tabular}{|c|c|c|c|c|}
\hline \multirow[b]{2}{*}{ Neuropeptide } & \multicolumn{4}{|c|}{ Main effect } \\
\hline & $\begin{array}{l}\text { Immunoglobulin } \\
\text { production }\end{array}$ & $\begin{array}{l}\text { Cytokine } \\
\text { secretion }\end{array}$ & $\begin{array}{l}\text { Cell-mediated } \\
\text { immunity }\end{array}$ & Inflammation \\
\hline Adrenocorticotrophic hormone & $\downarrow$ & $\uparrow \downarrow$ & $\downarrow$ & - \\
\hline Corticotrophin-releasing hormone & $\downarrow$ & $\uparrow \downarrow$ & $\downarrow$ & $\downarrow$ \\
\hline Vasopressin & - & - & - & $\uparrow$ \\
\hline$\beta$-Endorphin & $\uparrow$ & $\uparrow \downarrow$ & $\uparrow$ & $\uparrow$ \\
\hline$\alpha$-Melanocyte-stimulating hormone & - & $\downarrow$ & $\downarrow$ & $\downarrow$ \\
\hline Enkephalin & $\uparrow$ & $\uparrow$ & $\uparrow$ & $\uparrow$ \\
\hline Calcitonin gene-related peptide & - & $\downarrow$ & - & $\downarrow$ \\
\hline Nerve growth factor & $\uparrow$ & - & - & $\uparrow \downarrow$ \\
\hline Somatostatin & $\downarrow$ & $\uparrow \downarrow$ & - & $\uparrow \downarrow$ \\
\hline Substance $P$ & $\uparrow \downarrow$ & $\uparrow$ & - & $\uparrow$ \\
\hline Vasoactive intestinal peptide & $\uparrow \downarrow$ & $\downarrow$ & $\uparrow \downarrow$ & - \\
\hline
\end{tabular}

$\uparrow$, increased response/activity; $\downarrow$, decreased response/activity; $\uparrow \downarrow$, variable response.

during the first decade of life. Thereafter, the involution process decreases progressively (19). Connective and adipose tissues replace most of the thymic tissue, although some functional tissue remains throughout life $(19,20)$.

The thymus is covered by a thin connective tissue capsule and lobulated by septa originating from it. Septa, carrying vessels and nervous fibres, penetrate from the capsule to the central part of the organ designing the structure of cortex and medulla. These two regions can be distinguished because of the different density of the lymphoid cells. The medulla exhibits small and medium-sized lymphoid cells, as well as its typical

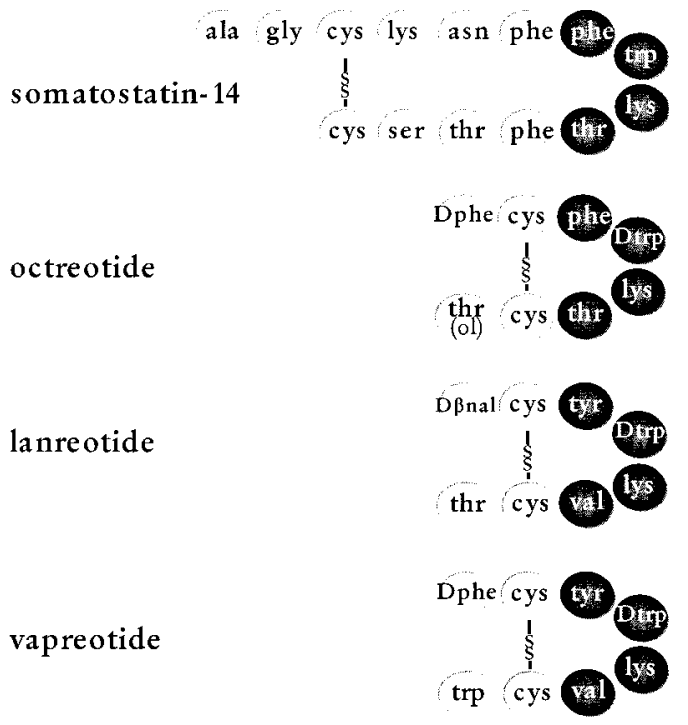

Figure 1 Amino acid sequences of native SS-14 and synthetic stable octapeptide analogues octreotide (SMS 201-995), lanreotide (BIM23014) and vapreotide (RC-160). The darker shading indicates the amino acids essential for binding with the receptor.
Hassall's corpuscles. The thymus has four principal cell types: thymocytes, the so-called 'lymphocytes of the thymus', which are the precursors of peripheral $\mathrm{T}$ lymphocytes; few macrophages and dendritic cells, which are all cells of bone marrow origin. The fourth type is a heterogeneous population of specialized thymic epithelial cells (TEC), which provide a supporting framework (the stroma) for the parenchyma. TEC, together with macrophages and dendritic cells drive the maturation and differentiation of thymocytes into mature lymphocytes, through cell-to-cell contacts and via soluble products. Thymic epithelium is a heterogeneous tissue, and cells in different locations within the lobules influence specific steps in thymocyte maturation. At least three phenotypically different types of epithelial cells are present in the thymus, cortical TEC, medullary TEC, and subcapsular epithelium. However, it seems that more subsets may be distinguished and identified on the basis of different content and type of cytokeratin (21). A schematic structure of a human thymic lobule is shown in Fig. 2.

In the thymus, the immature $\mathrm{T}$ cells proliferate and differentiate. The positively selected cells migrate to the Tcell-dependent areas of peripheral lymphoid organs, such as spleen, lymph nodes and tonsil (22). This process persists throughout life; however, the number of developing elements decays with ageing. Together with differentiation, precursors of $\mathrm{T}$ cells interact with various components of the thymic microenvironment (22). During migration, thymocytes follow a predisposed direction and are driven from the cortex to the medulla. In the first step, after a very active proliferative phase, thymocytes with high avidity are negatively selected and deleted by apoptosis, while those with intermediate avidity for recognition of major histocompatibility complex-self peptide are rescued and positively selected. Positive selection seems mainly mediated by TEC, whereas bone marrow-derived cells (macrophages and dendritic cells) essentially exert negative selection $(22,23)$. 




Figure 2 Schematic reproduction of a thymic lobule. Thymocytes during maturation are driven from the cortex to the medulla having, in the meantime, many contacts with a heterogeneous cellular network, including TEC, dendritic cells and macrophages. TEC represent a heterogeneous group with a distinct subset of cells in the cortex and in the medulla. Hassall's corpuscles probably represent sites of cell destruction and are typically localized in the medulla.

\section{Neuroendocrine control of the human thymus}

Pituitary hormones, thyroid hormones, steroids and neuropeptides can indirectly and directly modulate thymocyte development, conveying positive and negative signals for thymocyte proliferation (24). Moreover, evidence that cytokine production by thymocytes may be under neuroendocrine control has been provided (25-27). The intrathymic production of many of these factors, as well as the expression of their specific receptors, has been characterized during recent years (Table 2). Thus, in addition to the classical endocrine pathways, paracrine and autocrine mechanisms are implicated in the influence of hormones and neuropeptides on the thymus (24). This strongly suggests that normal circulating levels as well as controlled local production of these factors are necessary to preserve the homeostasis and the various biological functions related to both the microenvironmental and lymphoid cells of this important organ. Recently, our research has been focused on SS and its receptors as clinical consequences of their local activity in the cross-talk between specific subsets of thymic cells in both normal and pathological events in the human thymus.

\section{Distribution and significance of SS and SST in the human thymus}

SS-binding sites have been demonstrated in various human lymphoid tissues $(28,29)$. Binding studies and reverse transcriptase-polymerase chain reaction (RTPCR) analysis have been used to characterize SS and SST subtype expression in the normal human thymus. SS and three SST subtypes, sst $_{1}$, sst $_{2 \mathrm{~A}}$ and sst $_{3}$ have been found in thymic tissue (30). The expression of these different subtypes appeared heterogeneous within the tissue and on different cell subsets. A selective expression of $\mathrm{sst}_{1}$ and $\mathrm{sst}_{2 \mathrm{~A}}$ has been found on cultured TEC, in line with the evidence of $\left.{ }^{125} \mathrm{I}_{-} \mathrm{Tyr}^{3}\right]$-octreotide binding in the thymic medulla, where TEC is the prevalent cell type. TEC were also found to be a potential source of SS production within the thymus, since SS mRNA has been detected in these cells (30). Conversely, SS mRNA was undetectable in thymocytes and the distribution of SST subtypes on this heterogeneous cell population appears to be rather more complex (31). In fact, in freshly isolated thymocytes, $\mathrm{sst}_{2 \mathrm{~A}}$ and $\mathrm{sst}_{3} \mathrm{mRNA}$ expression has been detected while, in long-term cultured thymocytes, no mRNA encoding for SST subtypes was detectable, suggesting a relatively rapid down-regulation of SSTs on thymocytes during culture (D Ferone, PM van Hagen, SWJ Lamberts \& LJ Hofland, unpublished observations). Moreover, thymocytes at different levels of maturation seemed to express variable amounts of $\mathrm{sst}_{2 \mathrm{~A}}$ and $\mathrm{sst}_{3}$ mRNA compared with those in the whole population. In general, the number of SSbinding sites on thymocytes is low (32). This is in agreement with the presence of a low number of SSbinding sites on circulating human T lymphocytes (33), which derive from thymocytes. Finally, on macrophages, 
Table 2 Hormones, neuropeptides and their receptor expression within the thymus.

\begin{tabular}{lcc}
\hline Effector & $\begin{array}{c}\text { Intrathymic } \\
\text { production }\end{array}$ & $\begin{array}{c}\text { Receptor } \\
\text { expression }\end{array}$ \\
\hline 'Classic' hypothalamic peptides & & n.d. \\
GnRH & + & + \\
GHRH & + & n.d. \\
CRH & + & + \\
TRH & + & + \\
SS & + & \\
'Classic' anterior pituitary hormones & & + \\
ACTH & + & + \\
GH & + & + \\
PRL & + & n.d. \\
LH & + & + \\
'Classic' posterior pituitary hormones & & + \\
Vasopressin & + & + \\
Oxytocin & + & + \\
Steroids and thyroid hormones & & + \\
Cortisol & n.d. & + \\
Oestradiol & n.d. & + \\
Progesterone & n.d. & + \\
Testosterone & n.d. & + \\
Tri-iodothyronine/thyroxine & n.d. & + \\
Miscellaneous & & + \\
Insulin & + & + \\
Enkephalin & + & + \\
$\beta$-Endorphin & + & + \\
VIP & + & + \\
PACAP & n.d. & + \\
CGRP & & + \\
\hline GnRH, & + \\
\hline
\end{tabular}

$\mathrm{GnRH}$, gonadotrophin-releasing hormone; GHRH, growth hormonereleasing hormone; $\mathrm{CRH}$, corticotrophin-releasing hormone; $\mathrm{TRH}$, thyrotrophin-releasing hormone; ACTH, adrenocorticotrophic hormone; $\mathrm{GH}$, growth hormone; PRL, prolactin; $\mathrm{LH}$, luteinizing hormone; VIP, vasoactive intestinal peptide; PACAP, pituitary adenylate cyclase-activating polypeptide; CGRP, calcitonin generelated peptide; n.d., not detected

the third thymic cell component examined, the presence of only sst $_{2 \mathrm{~A}}$ mRNA was detected (D Ferone, PM van Hagen, SWJ Lamberts \& LJ Hofland, unpublished observations). This finding is in agreement with previous reports showing the selective expression of this SST subtype on human macrophages and monocytes $(34,35,69)$. The presence of functional SST subtypes on TEC and thymocytes has been demonstrated by in vitro studies on isolated cell cultures using SS and the SS analogue octreotide $(30,32)$. In our experience, both these compounds inhibited the basal and growth factor-stimulated TEC proliferation (30). However, preliminary data showed a dose-dependent inhibitory effect of SS on resting human thymocytes as well (D Ferone, PM van Hagen, SWJ Lamberts \& LJ Hofland, unpublished observations).

An additional important piece of evidence is that the expression pattern of SST subtypes in the thymus seems to show a species-specific distribution. In fact, there are substantial differences between man and the two more extensively studied animal models, i.e. the rat and the mouse (36-39). These differences make both these two models rather unsuitable for studying the effects of SS on human thymic cells. Also the local production of SS seems to have a different source in mouse and human. In fact, SS mRNA has been found in human TEC, but not in thymocytes or monocyte/macrophage lineage cells, whereas in mouse the peptide is mainly present in macrophages $(30,40)$.

Taking into consideration the peculiar human thymic microenvironment, its architecture and the specific pattern of SST distribution, the existence of specialized areas where SS and its receptors might exert differential activities may be hypothesized. On microenvironmental cells, sst $_{2 \mathrm{~A}}$ seems to be the receptor predominantly expressed and an autocrine or paracrine activity of SS could be involved in controlling the different functions of these cells. As has already been mentioned, a potential role for the neuropeptide in controlling TEC growth is suggested by the inhibitory effect of both SS and its octapeptide analogue octreotide on unstimulated and growth factor-stimulated proliferation of cultured TEC (30). Interestingly, pituitary hormones, which are under hypothalamic SS control, such as growth hormone and prolactin, as well as insulin-like growth factor-I enhance TEC proliferation (41-43). However, since sst $_{2 \mathrm{~A}}$ is the SST subtype mainly involved in controlling secretion processes by neuroendocrine cells, the possibility that this might be valid for thymic cells as well cannot be ruled out. In fact, TEC and macrophages produce a significant number of thymic hormones and cytokines, and these thymic secretory substances have previously been demonstrated to be influenced by other neuroendocrine factors (24). Both TEC and macrophages drive the maturation of thymocytes and are actively implicated in the positive and negative selection of the future $\mathrm{T}$ lymphocytes. The presence of specific SST on these cells suggests the involvement of the neuropeptide in regulating these highly specialized cell activities in the thymus. On the other hand, SS and other neuropeptides have been reported to effectively modulate proliferation, cytokine production and antigen presentation by macrophages in the skin under physiological and pathophysiological conditions (44).

The pattern of SST subtype expression on thymocytes seems to follow a predisposed order related to the different stage of maturation of the lymphoid cells. Moreover, $\mathrm{sst}_{3}$ is the SST subtype mainly expressed on thymocytes (D Ferone, PM van Hagen, SWJ Lamberts \& LJ Hofland, unpublished observations). Interestingly, this receptor seems to be selectively expressed on peripheral resting $\mathrm{T}$ lymphocytes, which directly derive from mature thymocytes (33). In the thymus, the majority of thymocytes are destined to die as a consequence of failing selection (45). Since cell death in the thymus occurs by apoptosis, the expression of the $\mathrm{sst}_{3}$ on these cells is intriguing. In fact, this SST subtype may be involved in agonist-mediated apoptosis (46). The presence of a receptor involved in this sophisticated 
process suggests a modulatory activity of SS in thymocyte deletion. However, further studies should elucidate whether SS might have an inductive or protective effect on programmed cell death in the human thymus. Recently, potent inductors of apoptosis in thymocytes, such as glucocorticoids, have been found to be implicated in the rescue of thymocytes from activation-induced cell death (47).

Emerging data are showing adhesion molecules, extracellular matrix ligands and receptors involved in driving thymocyte traffic, in terms of entrance of precursors, migration within the thymus, as well as exit of mature cells from the organ. This process seems to be influenced by neuroendocrine products as well (48-52). Since SS and other neuropeptides are involved in regulating the migration of immune cells in other compartments throughout the human body $(53,54$, 55), and considering the peculiar distribution of SST within the thymus, SS might play a role in the modulation of this mechanism. This aspect may be important considering that a disturbance in this process could favour traffic of immature or wrongly selected cells towards peripheral lymphoid organs, enabling the development of autoimmune diseases.

The recent availability of antibodies specific for $\mathrm{sst}_{2 \mathrm{~A}}$ and $\mathrm{sst}_{3}$ receptors made it possible to further investigate the cellular localization of these receptor subtypes by immunohistochemistry in human lymphoid tissues (34, $35)$. In general, sst $_{2 \mathrm{~A}}$ immunoreactivity has been found mainly located in areas where stromal cells are prevalent, while $\mathrm{sst}_{3}$ immunoreactivity occurred preferentially on cells with lymphoid morphology. The $s_{2 \mathrm{~A}}$ immunoreactivity, preferentially located in the medulla of the thymus is in agreement with the binding of the

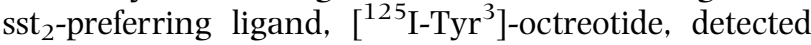
by SST autoradiography, and with the expression of sst $_{2 \mathrm{~A}}$ mRNA in isolated TEC $(30,31)$.

A final, but not less important, potential activity of SS within the thymus might be its involvement in the control of the physiologic involutive process that occurs in this lymphoid organ with ageing. The human thymus undergoes involution and decreases its activity in producing mature $\mathrm{T}$ cells. However, recent evidence points at the maintenance of an 'endocrine' activity of this organ, which might need a differential regulation during ageing (19). Binding studies with the sst $_{2^{-}}$

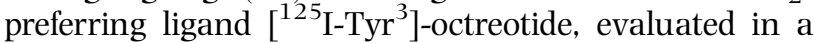
large series of human thymuses by SST autoradiography and ligand binding on tissue homogenates, showed an inverse correlation between the number of SS-binding sites and the chronological age of the thymus (56). In fact, the score at autoradiography, as well as the number of SST at membrane homogenate binding $\left(\mathrm{B}_{\mathrm{max}}\right)$ were inversely correlated with the thymus age $(P<0.001)$. Further studies are required to clarify whether the decrease of SST in the human thymus during ageing is a programmed step during involution or whether it is a consequence of the process in itself (56).
The local production of SS in the human thymus seems to be extremely relevant since the neuropeptide might act at different levels, on different thymic cells and via different receptor subtypes. Within the human thymus, SS might be considered as a potential modulator of the homeostasis of various cell components as well as a regulator of their specialized activities. Moreover, SS seems to directly participate in the main thymic function, namely the maturation of the human T cell repertoire. The hypothesis of multiple functions of SS in the thymus is in line with the similar observation for another well-known neuropeptide, VIP. In fact, both SS and VIP are produced within this organ and a strong compartmentalization of their respective receptors has been shown on human thymic cells (57). Like SST, the two VIP receptor subtypes display a distinct distribution in different thymocyte subsets, at least on murine and rat thymus, confirming that the expression of neuropeptide receptors could be differentially regulated during development (58). Finally, VIP may also affect multiple aspects of thymic cell functions $(57,58)$. An integrated role for these two neuropeptides, possibly together with substance $\mathrm{P}(\mathrm{SP})$, has already been hypothesized (28). However, the exact parameters regulating a hypothetical intrathymic circuit between these three substances have not yet been established. In general, in different pathophysiological conditions SS and VIP seem to 'counteract' the effect of SP on immune cells (58-60). However, in other situations, SS and VIP may have opposite effects on specific cell subsets, while acting synergistically on others (61).

The hypothesis on the relevance of SS and SST in thymus physiology discussed above form the basis for a better understanding of some mechanisms which may occur in pathological conditions of this organ.

\section{Distribution and significance of SS and SST in human thymic tumours}

Human thymoma is the most common tumour of the anterio-superior mediastinum and is composed of cytologically bland, neoplastic TEC accompanied by a variable admixture of benign lymphocytes (62). This tumour is frequently associated with paraneoplastic phenomena, such as myasthenia gravis, and/or other autoimmune-related disorders and haematological abnormalities (62). Like other tumours originating from SS-target tissues, human thymic epithelial tumours may express SST. These neoplasms have been visualized in vivo during SST scintigraphy using $\left[{ }^{111}\right.$ In-DTPA-d-Phe $\left.{ }^{1}\right]$-octreotide $(63,64)$. Although ligand-binding studies failed to detect SST on cryostat sections of human thymomas, at least three SST subtypes have been detected by immunohistochemistry using polyclonal antibodies specific for $\mathrm{sst}_{1}, \mathrm{sst}_{2 \mathrm{~A}}$ and sst $_{3}$ receptors $(28,65)$. Moreover, in one case the expression of SST subtypes was confirmed at mRNA 
level by RT-PCR analysis (65). Since the number of receptors in normal thymic tissue as well as in thymoma is rather low, different sensitivity of the two methods might, in part, explain this discrepancy. Preliminary data showed the expression of $\mathrm{sst}_{2 \mathrm{~A}}$ and $\mathrm{sst}_{3}$ receptors in a series of human thymic tumours visualized by in vivo SST scintigraphy (D Ferone, PM van Hagen, SWJ Lamberts \& LJ Hofland, unpublished observations). Considerable heterogeneity of SST immunoreactivity was found within and among the tumours. The heterogeneity of SST expression and the density of different receptor subtypes might play a crucial role in determining the in vivo uptake of radiolabelled SS analogues. Preliminary data suggest that the presence of sst $_{2}$ receptors is not an essential prerequisite for the visualization of SST-positive tissues during $\left[{ }^{111} \mathrm{In}-\mathrm{DTPA}\right.$ d-Phe ${ }^{1}$-octreotide scintigraphy (65). Moreover, sst $_{3}$ receptors have been shown to display the highest amount of agonist-dependent receptor internalization compared with the other SST subtypes (66). Although the affinity of octapeptide SS analogues for $\mathrm{sst}_{3}$ is lower compared with that for $\mathrm{sst}_{2}$, the high internalization of $\mathrm{sst}_{3}$ receptors might be the possible mechanism regulating the in vivo uptake of $\left[{ }^{111}\right.$ In-DTPA-d-Phe $\left.{ }^{1}\right]$ octreotide within thymomas. Indeed, $\mathrm{sst}_{3}$ seems to be the subtype predominantly expressed in thymomas. Another suggested hypothesis, which cannot be completely excluded, is the presence of a novel unidentified SST involved in determining the in vivo uptake of the radiotracer.

Receptor turnover and binding properties might be regulated differently in lymphoid cells compared with neuroendocrine cells. In fact, the activation of SST subtypes on lymphoid cells may induce opposite responses compared with endocrine cells $(9,10,67)$. It has been suggested that thymocytes, which are the major cell population in the human thymus, can rapidly down-regulate the expression of their SST when cultured in vitro (29). Thymocytes are cells with a wide plasticity in terms of modulation and expression of surface molecules. From this point of view it would be interesting to investigate what happens in reactive thymocytes in thymomas.

In general, in light of these findings it may be hypothesized that, on the basis of its binding properties and receptor affinity, $\left.{ }^{125} \mathrm{I}_{-} \mathrm{Tyr}^{3}\right]$-octreotide may be considered as a clear sst $_{2}$-preferring ligand for in vitro binding studies. In vivo, several exogenous factors may influence these properties, playing a role in determining the uptake of $\left[{ }^{111}\right.$ In-DTPA-d-Phe $\left.{ }^{1}\right]$-octreotide within SST-expressing tissues and tumours as well. This is a point that may have important consequences for future applications of the currently available SS analogue for systemic radiotherapy, as well as for the development and use of novel subtype-selective analogues and antagonists. Data in the literature point to a certain efficacy of treatment with SS analogues in neoplastic diseases involving organs of the immune system and in autoimmune diseases $(9,10)$. Of particular interest is the reported successful treatment of patients bearing thymomas associated with paraneoplastic syndromes with the SS analogue octreotide or with the combination of octreotide and corticosteroids $(64,68)$. As far as the effect on the autoimmune disease is concerned, further studies should investigate whether the effect of therapy with SS analogues may have a rationale in the treatment of the severe autoimmune diseases, which are frequently associated with thymic disturbances.

The heterogeneity of SST expression pattern in thymic tumours and the reported effects on the tumour mass exerted by therapy with SS analogues might represent another stimulating field for future investigations. In fact, in one paradigmatic case displaying a significant in vivo uptake of $\left[{ }^{111} \mathrm{In}\right.$-DTPA-d-Phe $\left.{ }^{1}\right]$-octreotide and a preferential expression of $\mathrm{sst}_{3}$ receptor, a significant inhibition of cell proliferation by SS and octreotide has been shown in vitro (65). SS is endogenously produced in the normal thymus, suggesting a role of the neuroeptide in controlling cell homeostasis in this organ. Conversely, in this thymoma SS mRNA was undetectable (65). Although very speculative, the loss of SS in a tumour arising from this organ might be involved in the pathogenesis of the neoplastic transformation as well as in the pathogenesis of the associated autoimmune diseases. However, as previously underlined, thymomas represent a highly heterogeneous class of tumours and further investigations are mandatory to elucidate the significance of SS and specific SST subtype expression in this class of tumours.

\section{Conclusions}

SST on target cells can be actively up- or downregulated by exposure to several heterologous agents, as well as to its own ligand. In general, changes in the density, quality and activity of local regulatory factors might alter the distribution and concentration of neuropeptide receptors and their ligands. This may also apply to the human thymus, where the global activity of the organ is based on the balance of several regulating factors produced locally.

We can conclude that SS and a set of SST are expressed in the human thymus in both microenvironmental and lymphoid cells in an apparently selective manner. A highly specialized intrathymic circuit seems to integrate SS in the main function of this organ as well as in other activities, which needs further investigation. The age-related involution of this lymphoid organ and the occurrence of thymic tumour-related autoimmune diseases are two of the main aspects in which SS and SST might be involved. However, this points out the important role of the neuropeptide and its receptors in thymic homeostasis. The overall activity of the thymus is based on the balance of several regulating factors, which can be locally produced. Disturbances in this delicate equilibrium may lead to the induction of 
unbalanced immune responses. Since alterations in the circuit involving SS might be implicated in the pathogenesis of these diseases, therapy with SS analogues might have an application in specific thymusrelated immune disorders.

\section{References}

1 Besedovsky H \& Del Rey A. Immune-neuro-endocrine interactions: facts and hypothesis. Endocrine Reviews 199617 64-102.

2 Blalock JE. The syntax of immune-neuroendocrine communication. Immunology Today 199415 504-511.

3 Blalock JE. Shared ligands and receptors as a molecular mechanism for communication between the immune and neuroendocrine systems. Annals of the New York Academy of Sciences $1994741292-298$.

4 Roth J, LeRoith D, Collier ES, Weaver NR, Watkinson A, Cleland $\mathrm{CF}$ et al. Evolutionary origins of neuropeptides, hormones, and receptors: possible applications to immunology. Journal of Immunology $1985135816 \mathrm{~s}-819 \mathrm{~s}$.

5 Berczi I, Chalmers IM, Nagy E \& Warrington RJ. The immune effects of neuropeptides. Baillieres Clinical Rheumatology 199610 227-257.

6 Weinstock JV. Tachykinin production by granuloma eosinophils in murine Schisostomiasis mansoni. In Inflammatory Bowel Diseases: Current Status and Future Approach, pp 335-341. Ed. RP MacDermott. Amsterdam: Elsevier, 1988.

7 Fuller PJ \& Verity K Somatostatin gene expression in the thymus gland. Journal of Immunology 1989143 1015-1017.

8 Aguila MC, Dees WL, Haensly WE \& McCann SM. Evidence that somatostatin is localized and synthesized in lymphatic organs. PNAS 199188 11485-11489.

9 van Hagen PM, Krenning EP, Kwekkeboom DJ, Reubi JC, AnkerLugtenburg PJ, Löwenberg B et al. Somatostatin and the immune and haematopoietic system; a review. European Journal of Clinical Investigation 199424 91-99.

10 Ferone D, van Hagen PM, Colao A, Lombardi G, Lamberts SWJ \& Hofland LJ. Distribution, role and function of somatostatin receptors in immune cells. In Octreotide: The Next Decade, pp 259-275. Ed. SWJ Lamberts. Bristol: BioScientifica Ltd, 1999

11 Lamberts SWJ. The role of somatostatin in the regulation of anterior pituitary hormone secretion and the use of its analogs in the treatment of pituitary tumors. Endocrine Reviews 19889 417-436.

12 Lamberts SWJ, Krenning EP \& Reubi JC. The role of somatostatin and its analogs in the diagnosis and treatment of tumors. Endocrine Reviews 199112 450-482.

13 Lamberts SWJ, van der Lely A-J, de Herder WW \& Hofland LJ. Octreotide. New England Journal of Medicine 1996334 246-254.

14 Patel YC, Greenwood MT, Panetta R, Demchyshyn L, Niznik H \& Srikant CB. The somatostatin receptor family. Life Sciences 1995 57 1249-1265.

15 Hoyer D, Bell GI, Berelowitz M, Epelbaum J, Feniuk W, Humphrey $\mathrm{PP}$ et al. Classification and nomenclature of somatostatin receptors. Trends in Pharmacological Sciences $19951686-88$.

16 Reisine T \& Bell GI. Molecular biology of somatostatin receptors. Endocrine Reviews 199516 427-442.

17 Patel YC. Molecular pharmacology of somatostatin receptor subtypes. Journal of Endocrinological Investigation 199720348 367.

18 Stanisz AM, Befus D \& Bienenstock J. Differential effects of vasoactive intestinal peptide, substance $P$, and somatostatin on immunoglobulin synthesis and proliferation by lymphocytes from Peyer's patches, mesenteric lymph nodes, and spleen. Journal of Immunology $1986136152-156$.

19 Steinmann GG. Changes in the human thymus during ageing. In Current Topics in Pathology: The Human Thymus, pp 43-88. Ed. HK Müller-Hermelink. Berlin, Heidelberg: Springer-Verlag, 1986.
20 Kendall MD. Age and seasonal changes in the thymus. In The Thymus Gland, pp 21-35. Ed. MD Kendall. London: Academic Press, 1981.

21 Laster AJ, Itoh T, Palker T \& Haynes BF. The human thymic microenvironment: thymic epithelium contains specific keratins associated with early and late stages of epidermal keratinocytes maturation. Differentiation 198631 67-77.

22 Anderson G, Moore NC, Owen JJT \& Jenkinson EJ. Cellular interactions in thymocyte development. Annual Review of Immunology 199614 73-99.

23 Nossal GJV. Negative selection of lymphocytes. Cell $199476229-$ 239.

24 Savino W, Villa-Verde DMS, Alves LA \& Dardenne M. The neuroendocrine control of the thymus. Annals of the New York Academy of Sciences 1998840 470-479.

25 Rameshwar P, Gascon P \& Ganea D. Immunoregulatory effects of neuropeptides: stimulation of interleukin-2 production by substance P. Journal of Neuroimmunology 199237 65-73.

26 Ganea D. Regulatory effects of vasoactive intestinal peptide on cytokine production in central and peripheral lymphoid organs. Advances in Neuroimmunology 19966 61-74.

27 Tang H, Sun L, Xin Z \& Ganea D. Down-regulation of cytokine expression in murine lymphocytes by PACAP and VIP. Annals of the New York Academy of Sciences 1996805 768-778.

28 Reubi JC, Waser B, Horisberger U, Krenning E, Lamberts SWJ, Gebbers J-O et al. In vitro and in vivo scintigraphic localization of somatostatin receptors in human lymphatic tissue. Blood 1993 82 2143-2151.

29 van Hagen PM, Hofland LJ, Lichtenauer-Kaligis EGR, ten Bokum AM, Ferone D \& Lamberts SWJ. Neuropeptides and their receptors in the immune system. Annals of Medicine 199931 15-22.

30 Ferone D, van Hagen PM, van Koetsveld PM, Zuijderwijk J, Mooy DM, Lichtenauer-Kaligis EGR et al. In vitro characterization of somatostatin receptors in the human thymus and effects of somatostatin and octreotide on cultured thymic epithelial cells. Endocrinology 1999140 373-380.

31 Ferone D, van Hagen PM, Colao A, Annunziato L, Lamberts SWJ \& Hofland LJ. Somatostatin receptors in the human thymus. Annals of Medicine 199931 28-33.

32 Söder O \& Hellström PM. Neuropeptide regulation of human thymocyte, guinea pig $\mathrm{T}$ lymphocyte and rat $\mathrm{B}$ lymphocyte mitogenesis. International Archives of Allergy and Applied Immunology $198784205-211$.

33 Ghamrawy CE, Rabourdin-Combe C \& Krantic S. sst5 somatostatin receptor mRNA induction by mitogenic activation of human T-lymphocytes. Peptides 199920 305-311.

34 ten Bokum AMC, Melief MJ, Schonbrunn A, van der Ham F, Lindeman J, Hofland LJ et al. Immunohistochemical localization of somatostatin receptor $\mathrm{sst}_{2 \mathrm{~A}}$ in human rheumatoid synovium. Journal of Rheumatology $199926532-535$.

35 ten Bokum AMC, Hofland LJ, de Jong G, Bouma J, Melief MJ, Kwekkeboom DJ et al. Immunohistochemical localization of somatostatin receptor $\mathrm{sst}_{2 \mathrm{~A}}$ in sarcoid granulomas. European Journal of Clinical Investigation 199929 630-636.

36 Scicchitano R, Dazin P, Bienenstock J, Payan DG \& Stanisz AM. Distribution of somatostatin receptors on murine spleen and Peyer's patch T and B lymphocytes. Brain, Behavior, and Immunity 19871 173-184.

37 Elliot DE, Metwali A, Blum AM, Sandor M, Lynch R \& Weinstock JV. $\mathrm{T}$ lymphocytes isolated from hepatic granulomas of schistosomeinfected mice express somatostatin receptor subtype II (SSTR2) messenger RNA. Journal of Immunology 1994153 1180-1186.

38 Sedqi M, Roy S, Mohanraj D, Ramakrishnan S \& Loh HH. Activation of rat thymocytes selectively upregulates the expression of somatostatin receptor subtype-1. Biochemistry and Molecular Biology International 199638 103-112.

39 ten Bokum AMC, Lichtenauer-Kaligis EGR, Melief MJ, van Koetsveld PM, Bruns C, van Hagen PM et al. Somatostatin receptor subtype expression in cells of the rat immune system during adjuvant arthritis. Journal of Endocrinology 1999161 167-175. 
40 Throsby M, Pleau J-M, Dardenne M \& Homo-Delarche F. Thymic expression of pancreatic endocrine hormones. Neuroimmunomodulation 19996 108-114.

41 Dardenne M, Savino W, Gagnerault MC, Itoh I \& Bach JF Neuroendocrine control of thymic hormonal production. I. Prolactin stimulates in vivo and in vitro the production of thymulin by human and murine thymic epithelial cells. Endocrinology 1989123 2557-2564.

42 Timsit J, Savino W, Safieh B, Chanson P, Gagnerault MC, Bach JF et al. Growth hormone and insulin-like growth factor-I stimulate hormonal function and proliferation of thymic epithelial cells Journal of Clinical Endocrinology and Metabolism 199275 183-188.

43 Andersen A, Pedersen H, Bendtzen K \& Röpke C. Effects of growth factors on cytokine production in serum-free cultures of human thymic epithelial cells. Scandinavian Journal of Immunology 1993 $38233-238$.

44 Scholzen T, Armstrong CA, Bunnet NW, Luger TA, Olerud JE \& Ansel JC. Neuropeptides in the skin: interactions between the neuroendocrine and the skin immune systems. Experimental Dermatology $1998781-96$.

45 Owen JJ \& Jenkinson EJ. Apoptosis and T cell selection in the thymus. Annals of the New York Academy of Sciences 1992663 305-310.

46 Sharma K, Patel YC \& Srikant CB. Subtype-selective induction of wild-type p53 and apoptosis, but not cell cycle arrest by human somatostatin receptor 3. Molecular Endocrinology 1998101688 1696.

47 Tolosa E \& Ashwell JD. Thymus-derived glucocorticoids and the regulation of antigen-specific T-cell development. Neuroimmunomodulation 19996 90-96.

48 Taub DD, Tsarfaty G, Lloyd AR, Durum SK, Longo DL \& Murphy WJ. Growth hormone promotes human $\mathrm{T}$ cell adhesion and migration to both human and murine matrix proteins in vitro and directly promotes xenogeneic engraftment. Journal of Clinical Investigation 199494 293-300.

49 Bomberger CE \& Haar JL. Dexamethasone and hydrocortisone enhance the in vitro migration of prethymic stem cells to thymus supernatant. Thymus 199220 89-99.

50 Delgado M, De la Fuente M, Martinez C \& Gomariz RP. Pituitary adenylate cyclase-activating polypeptides (PACAP 27 and PACAP 38) inhibit the mobility of murine thymocytes and splenic lymphocytes: comparison with VIP and implication of cAMP. Neuroimmunomodulation 19952 313-318.

51 Ribeiro-Carvalho MM, Smaniotto S, Savino W \& Mello-Coelho V. Hormonal influence on T cell migration. Neuroimmunomodulation $19996465-466$.

52 Morale MC, Batticane N, Gallo F, Barden N \& Marchetti B. Disruption of hypothalamic-pituitary-adrenocortical system in transgenic mice expressing type II glucocorticoid receptor antisense ribonucleic acid permanently impairs $\mathrm{T}$ cell function: effects on $\mathrm{T}$ cells trafficking and $\mathrm{T}$ cells responsiveness during postnatal development. Endocrinology 1995136 3949-3960.

53 Sacerdote P, Bianchi M \& Panerai AE. Human monocyte chemotactic activity of calcitonin and somatostatin related peptides: modulation by chronic peptide treatment. Journal of Clinical Endocrinology and Metabolism 199070 141-148.

54 Partsh G \& Matucci-Cerinic M. Effect of substance $\mathrm{P}$ and somatostatin on migration of polymorphonuclear (PMN) cells in vitro. Inflammation $199216539-547$.
55 Wiedermann CJ, Renisch N \& Braunsteiner H. Stimulation of monocyte chemotaxis by human growth hormone and its deactivation by somatostatin. Blood 199382 954-960.

56 Ferone D, Pivonello R, van Hagen PM, Waaijers M, Zuijderwijk J, Colao A et al. Age-related decrease of somatostatin receptor number in normal human thymus. American Journal of Physiology 2000 (In Press).

57 Reubi JC, Horisberger U, Kappeler A \& Laissue JA. Localization of receptors for vasoactive intestinal peptide, somatostatin and substance $\mathrm{P}$ in distinct compartment of human lymphoid organs. Blood 199892 191-197.

58 Delgado M, Martinez C, Leceta J \& Gomariz RP. Vasoactive intestinal peptide in thymus: synthesis, receptors and biological actions. Neuroimmunomodulation 19996 97-107.

59 Payan DG, Hess CA \& Goetzl J. Inhibition by somatostatin of the proliferation of T-lymphocytes and Molt-4 lymphoblasts. Cellular Immunology 198484 433-438.

60 Stanisz AM, Befus D \& Bienenstock J. Differential effects of vasoactive intestinal peptide, substance $\mathrm{P}$, and somatostatin on immunoglobulin synthesis and proliferation by lymphocytes from Peyer's patches, mesenteric lymph nodes, and spleen. Journal of Immunology 1986136 152-156.

61 Ottaway CA. Selective effects of vasoactive intestinal peptide on mitogenic response of murine T cells. Immunology 198762 291297.

62 Lewis JE, Wick MR, Scheithauer BW, Bernatz PE \& Taylor WF. Thymoma. A clinicopathologic review. Cancer 198760 27272743.

63 Lastoria S, Vergara E, Palmieri G, Acampa W, Varrella P, Caracò C et al. In vivo detection of malignant thymic masses by ${ }^{111} \mathrm{In}-$ DTPA-D-Phe $\left.{ }^{1}\right]$-octreotide scintigraphy. Journal of Nuclear Medicine $199839634-639$.

64 Lin K, Nguyen BD, Ettinger DS \& Chin BB. Somatostatin receptor scintigraphy and somatostatin therapy in the evaluation and treatment of malignant thymoma. Clinical Nuclear Medicine 1999 24 24-28.

65 Ferone D, van Hagen PM, Kwekkeboom DJ, van Koetsveld PM, Mooy DM, Lichtenauer-Kaligis EGR et al. Somatostatin receptors in human thymoma and inhibition of cell proliferation by octreotide in vitro. Journal of Clinical Endocrinology and Metabolism 200085 1719-1726.

66 Hukovic N, Panetta R, Kumar U \& Patel YC. Agonist-dependent regulation of cloned somatostatin receptor types 1-5 (hSSTR15): subtype selective internalization or upregulation. Endocrinology $19961374046-4049$.

67 Hofland LJ, van Hagen PM \& Lamberts SWJ. Functional role of somatostatin receptors on neuroendocrine and immune cells. Annals of Medicine 199931 23-27.

68 Palmieri G, Lastoria S, Colao A, Vergara E, Varrella P, Biondi E et al. Successful treatment of a patient with thymoma and pure redcell aplasia with octreotide and prednisone. New England Journal of Medicine 1997336 263-265.

69 Lichtenauer-Kaligis EGR, van Hagen PM, Lamberts SWJ \& Hofland LJ. Somatostatin receptor subtypes in human immune cells. European Journal of Endocrinology 143 (Suppl 1) 21-25.

Received 1 July 2000

Accepted 19 July 2000 